\title{
The Implementation of Hospital Ethics in the Public Service at Abepura Provincial Hospital, Jayapura
}

\author{
*Yosephina Ohoiwutun \\ Jonathan Salusu
}

Suradi Tahmir

Muhammad Akbar

\begin{abstract}
Universitas Negeri Makassar, Makassar, South Sulawesi, Indonesia, JIn. Bonto Langkasa Kampus UNM Gunung Sari Postal Code 90222; *yossi_ohoiwutun@yahoo.co.id, jonsalusu@gmail.com, radita_unm@yahoo.com, akbar80fkuh@gmail.com
\end{abstract}

\section{Doi:10.5901/mjss.2016.v7n1s1p222}

\section{Abstract}

The purpose of this study was to describe the implementation of the principles of ethics at Abepura Provincial Hospital. This research was a descriptive qualitative study using a case study approach. Data collection was through observation, in-depth interview, and documentation study. Data sources and informants consisted of the director of the provincial hospital, doctors, nurses, employees, patients and families of patients. Data analysis was conducted through data reduction, data presentation, data verification and conclusion. The results showed that ethic at Abepura Provincial Hospital have been implemented. However, it has not been optimal. It is reflected in the implementation of the obligations of hospitals that have not been conducted properly. In addition, a hospital as an organization that is filled by a wide range of professions does not yet have an ethics committee that can consider the violation of ethics in hospitals.

Keywords: Hospital Ethics, Hospitals Obligations, Public Service, Service Quality, Regional Public Hospital

\section{Introduction}

Humans may not be able to prosper themselves individually because they are zoon poloticon. Therefore, human welfare is organized through the agency or agencies that are empowered to enforce it. According to Gawthrop (1998, p. 53), in a democracy, the value of the role of government is to create the conditions so that citizens can achieve a good quality of life. Primary task of modern government, according to Rashid (1997, p. 11), is a service to the community. In other words, it is not to serve itself, but it is to serve the community as well as to create the conditions that enable every member of the community in developing ability and creativity in order to achieve a common goal.

One of the main functions of the government officials is organizing the public service as a manifestation of the collective task of government in order to realize the community welfare. Hardiyansah (2011, p. 20-23) asserts that the public service that must be provided by the Government can be classified into two main categories, namely: basic need services and public service. In addition, the basic needs that must be given by the government consist of basic health, education and other necessities.

In relation to the quality of medical services in hospitals, Aditama (2007, p. 157) states that the quality of health services refers to the ability of hospitals in providing services that comply with health standards and acceptable to patients. According to the Institute of Medicine Committee in the United States in Aditama, the quality of medical services is appraised of how that service either for individuals or populations can increase the degree of health and conduct in accordance with the development of science that exists at that time. Longest (1976) in Aditama (2007, p. 159), states that there are many aspects that can be used to assess the quality of health services. They are:

a) Refereed from "structure," it is the service itself and how the form of service provided

b) The process of granting of services can also be assessed to find out the quality. It covers the interactions between giver and service people served.

c) It observes the results of health services provided, such as mortality figures, and the number of nosocomial infections.

Jonas and Rosenberg in Aditama (2007, p. 159-161) reveal three aspects of the assessment of the quality of 
service. They are approaches, techniques and criteria. From the aspect of the approach, there are two approaches, namely general and particular approach. The general approach is performed by assessing the ability of hospitals and its staff members, and comparing it with the existing standard. Specific approach is conducted by assessing the relationship of interaction between patients and the service provider at the hospital. From the aspect of technique, the assessment can be presented with three components, namely: structure, process and results. The component structure is assessed from the condition of existing facilities, the physical building conditions, organizational structure, and the qualifications of the staff of the hospital. Components of the process are evaluated from what happens between the service provider and the service recipient. The component results are assessed from the results of the treatment, or the impact of treatment on health status and patient satisfaction. The quality of health services is multi-dimensional so that it is not easy to assess.

Victor and Cullen (1988, p. 101) reveal that every organization and every procedure that exist in an organization contain ethical values. The existence of ethics in organizations is crucial, despite ethical values in the organization does not automatically make better moral of an individual. However, ethics in an organization will assist a person in making better decisions [Bonzeck, (1992), p.75-89]. The dilemma faced by an administrator is not only how that public organization can run efficiently, but also how the organizations can provide a satisfactory service to the public [Kumorotomo, (2002), p.124]. Salusu (2004, p. 302) asserts that the organization should be able to provide satisfaction for consumers. It could happen if everyone in the organization avoids actions that are contrary to the principles of public ethics.

Sarundajang (2012, p. 250-251) states that there are some ethical values, which must be implemented by the government official in carrying out their duties and responsibilities. The first is the ethics of the profession. Each job or profession has a particular ethical code, which became a reference for government officials to think and judge the good and bad things. The second is the organizational ethics. All the public and private sector organizations, as well as social, have formal rules and ethics of the organization. The third is the social ethics. A government official is usually faced with ethical responsibility that is conducted to improve social welfare, justice, together with the guarantee of the rights of the individual.

Victor and Cullen (1988, p. 111-113), reveal that there are five main things to note that ethics can be applied by people in an organization. They are a legal profession, rules, instrumental, and Freedom. Pugh (1991, p. 18) states that the government officials should use the values of democracy in action, where the action contains some values. The first is respect for private ownership and equality. The second is respect for the rights of citizens to participate and the right to obtain information. The third is prioritizing the public interest above personal interests. The fourth is social equalization equitably. Gawthrop (1998, p. 53) states that the fair is one of the expected values owned by the government official.

Furthermore, Willbern (1984, p. 104) arranges some characteristic components of ethics and categorizes them into six components of morality. The first is honesty and obedience to the law. The second is a minimization of interest conflicts. The third is service orientation and procedure of justice. The fourth is a democratic liability. The fifth is the determination of ethical public policy. The sixth is a compromise and social integration. In addition, the first three categories are viewed as aspects of personal morality, whereas the remaining three categories are related to morality in the context of the implementation of the tasks performed by the government official.

The ethics of hospitals in Indonesia have been arranged by the organization of the hospital throughout Indonesia. It is Union of Hospitals throughout Indonesia (PERSI/Persatuan Rumah Sakit Seluruh Indonesia). Based on the formula of PERSI, hospital ethics consists of:

a) General obligation in the hospital

b) Obligations of hospitals toward the society

c) Obligations of hospitals toward patients

d) Obligations of hospitals toward employees of hospitals

e) Obligations of hospitals toward another Hospital

As a side note, any hospital can form a governing body that will deal with problems of ethics in the environment itself, by the Committee of ethics called PERSI hospital or the hospital ethical committee. Notoatmodjo (2010, p.158).

Organizational ethics hospital is currently undergoing major changes. The old form of organization ethics the hospital a lot rests on the relationship of doctors and patients in the context of the doctor's oath; however, hospital organizational ethic is meanwhile widely discussed the norms that are referenced in the management of the daily activities in hospitals [Lasono, (2000), p. 371). These norms reflect how the business of hospitals will be run so that in the end, the hospital can earn the trust of the community.

With the enacted Act No. 22 in 1999 enhanced through law number 32 in 2004 concerning the system of local governance; it is the responsibility of the public service has been delegated to units of the Organization closer to the people of the local governments. However, in fact, the implementation of this legislation has not yet been able to answer 
the challenges of public service quality will be better [Kumorotomo, (2008), p. 191]. The granting of special autonomy to Papua Province is intended to accelerate the attainment of community welfare through improved service, empowerment and participation of the community.

Article 59 (1) of the special autonomy law for Papua, which stated that the provincial government is obliged to set standards of quality and provide health services for the population (2005, p. 70). However, up to ten years special autonomy laws implemented have not fulfilled to the maximum as expressed by Winarno (2013, p. 229) that the lack of public services such as health and education needs provided by the Government after the special autonomy is still going on. Thus, a high-mortality rate in Papua was not only a result of illness and life patterns society, but the omission of its leader who is willing to help its people by building quality health facilities, sufficient equipment and manpower is adequate [Giyai, (2012), p. 132].

Public services in the field of health in Abepura District General Hospital have not been fullest exercised governmental apparatus was directly involved in the provision of public services in Abepura District General Hospital. It is as preached by one local daily newspaper about the case Fransisca 26 years old. She is a patient newly Abepura Hospital operated on and was still unconscious when officers take the dope drop tool on the forehead of the patient who causes new wounds on the forehead and cheeks swollen and result in broken teeth. As a result, the family reported to police person's Officer (Cenderawasih Post, April 27th, 2010, p. 10). Likewise, by the Director of the Provincial Hospital, Abepura said that to enhance the service to the community in the year 2012, Abepura Hospital first settled themselves with doing alterations and improvements to the services provided throughout the year 2011. Improvements will be made among them concerning the discipline and attitude of employees who are rated not by the rules, as well as much of the expected service standard (Cenderawasih Post, January 10th, 2012: 3). Based on the observations of the author in May 2012 that government bureaucracy, especially in Abepura Hospital in providing services not yet satisfactory, there are still patients who complain, because it was not receiving the service as it should be. For example, patients were not given the drug JAMKESPA for free as applicable provisions but asked to buy in pharmacies outside the hospital that cost quite expensive.

Based on the facts and the phenomenon, then it becomes important to describe the research done deep application of hospital ethics in the public service in General hospital in Abepura District Jayapura.

The purpose of this study was to assess and to describe the adoption of ethical principles in the public service hospital in Abepura Hospital-Jayapura.

\section{Literature Review}

Bertens (2007: 4-6) concluded that there are three important sense of ethics, namely:

1. Ethics are moral values and ethical norms that become a handle for a person or a group in regulating behavior or called by the value system.

2. Ethics are a set of principles or moral values, known by the code of conduct.

3. Ethics are a knowledge about good thing or bad thing; it called moral philosophy.

In the world of public administration or public service, ethics are defined as the philosophy and ethics of professional standards (code of ethics), or morals or the right rules of conduct (rules of good behavior) that should be observed by public service providers or public administrator (Denhard, 1988).

The term refers to the ethical norms or values that are abstract, and not yet written. If it had been written, he turns into a code of ethics (Triwibowo, 2012: 147). Hospital code of ethics is a summary of the values and norms which used as operational guidance that is needed, given the hospitals and the development of medical science and technology have become a unit of socioeconomic diversity. Inside the hospital, there are workers from different disciplines who have professional ethics so that spirit of togetherness is needed so hospitals can function properly (Sumijatun, 2012: 22).

Adikusumo (2003: 11) suggests that the hospital is an integral part of the overall health care system that was developed through the health development plan.

\section{Methodology}

This research is a descriptive qualitative study using a case study approach. Data collection carried through; observation, in-depth interviews (in-depth interview) and study the documentation. Data sources and informants in this study are; The Director of the Provincial Hospital, doctors, nurses, employees, patients and Families of patients. Data analysis was done by using models, Miles and Huberman (1992), namely through the reduction of data, data presentation, data verification and withdrawal of the conclusion. 
The approach was done to provide a systematic overview, factual and thorough about the application of ethical principles hospitals in providing services to the public.

\section{Results and Discussions}

In general, the application of hospital ethics in the public service in Abepura Regional General Hospital has not been executed despite an increase in optimal when compared to five years ago. It is reflected through the implementation of obligations of hospitals that have been fulfilled.

\subsection{General Obligations of Hospitals}

General Hospital obligations held by the Abepura Provincial Hospital have not optimally implemented, as one of the facilities of public service, which hosts the health service to the community. Abepura Provincial Hospital shall be obliged to provide services that adequate for organizing health services in accordance with the classification of a hospital that is owned. In addition to the hospitals have a duty to provide adequate service to organize health services for the people in the hospital, the hospital also has a responsibility to all the events that occurred in the hospital environment. Hospital responsibility as expressed by Guwandi in Triwibowo (2012, p. 50) that the hospital has four (4) areas of responsibility, namely: a) the responsibility of personnel, b) professional responsibility with respect to the quality of the treatment or care, c) the responsibility of the facilities and equipment, d) responsibility to the security of the building and her treatment. The responsibility of the hospital is very important because it deals with the obligation of public hospitals in providing a quality service for the community.

\subsubsection{Organizing Health Services}

In organizing health services for the community, Abepura Hospital have met the standards of as required by regulation of the Minister of health RI No. 340 in 2010, which as with type C hospitals. Abepura Hospital has been able to provide health services to the community by organizing medical services specialist; there are four bases, i.e. ministries of disease in surgical services, health care, children, and service of obstetrics and gynaecology. Moreover, supported by the presence of four specialists supporting the radiology clinic, pathology, Anatomy, Neurology/neurological and skin and sex services.

There are four basic medical services specialist at the Abepura Hospital Emergency Unit services (ER), outpatient, inpatient, laboratory, and radiology. Product service includes: outpatient installation includes Kids, Poly surgical, Poly obstetrics, the disease poly, Poly lungs, Poly physiotherapy, Poly teeth, eyes, Poly ENT, Poly nutrition. Inpatient installation includes VIP room, classrooms, the maternity room, surgical room, men's spaces, perinatology space, women's space, children's room, and ICU. Installation of emergency (IGD), installation Radiology, installation pharmacy, laboratory installation, installation maintenance means the Hospital (IPSRS), Laundry cleaning installation, installation of nutrition and Sanitary installation. Hospitals also have obtained the Abepura hospital accreditation certificate by the Commission on accreditation of hospitals (KARS) No. KARS-SERT/755/VI/2012 dated June 29, 2012, which decided that the Abepura Provincial Hospital has been declared passes the basic-level hospital accreditation, which includes the Ministry of administration and management, medical services, emergency services, nursing services and medical record service.

a) The responsibility of the hospital in providing personnel/human resources that organizes the tasks and functions of the hospital have not been fulfilled. Even though it increased, however, functional good staffs as well as specialist nurses who provide care and treatment services, and ancillary personnel still lack to support the units of service.

b) Professional responsibility of quality of treatment or treatment at the Abepura Hospital was affected by the presence of satisfaction of community toward service. That demonstrated by the increasing number of patient visits each year and the average rate of the BOR (bed occupancy Rate) or the number of beds use over the years in 2008-2012 is very high average of $77 \%$. It means that the BOR of Abepura Hospital stage is normal, considering the ideal BOR parameter values according to the Department of Health is $60-85 \%$. While the average BTO (Bed Turn Over) or the frequency of beds use during the years in 2008-2012 average 64 times a year, whereas the number in a year one BTO ideal bed used 40-50 times. High number of BOR and BTO shows high numbers of patients who visit also resulted in TOI (Turn Over Internal) or interval the use of very small beds in Abepura hospital only ranges between 0-2 day, ideally 2-3 days. Similarly, if seen from the death 
rate each year is declining (see table V. 16). It gives an overview that The Abepura Regional Public Hospital provides services that are getting better, but on the one hand has limitations of personnel and equipment.

c) The responsibility of the facilities and equipment. In this case the responsibility of the basic equipment the hotel and the hospital, as well as medical equipment in hospitals. From the data obtained in The Abepura Regional Public Hospital medical equipment and basic hospital equipment hospitality still lacks. Although it has experienced an increase in time, and with prepared of new medical equipment and sophisticated, but the equipment that is considered required in daily still has not been fulfilled.

d) Responsibility to the security of the building and the treatment. Support the tasks and functions of the hospital, and then the means/facilities of buildings belonging to The Abepura Regional Public Hospital still lack. However, the new building is under construction and building rehabilitation Abepura Hospital whereas for security and maintenance have not been optimally fulfilled.

\subsubsection{Provide Emergency Services}

In Abepura, Hospital has an emergency unit that carryout the service to the public 24 hours/day. Its commissioning was carried out in accordance with the standard procedures already fixed set by hospitals and carried out properly in accordance with the provisions and expectations of society.

\subsubsection{Implement and maintain the medical record}

Medical record made for the orderly administration of the hospital that is one of the deciding factors for the purpose of health care improvement efforts at the hospital. It is intended in order to obtain an accurate documents or records from patients regarding life and health history, a history of the disease in the past and present, also a treatment that has been given in an effort to improve the health service. The implementation of Medical Record on Abepura Hospital ran not optimal and subjected to constraints mainly in maintenance the storage area, room available was not adequate. Similarly, in organizing the recording still using manual systems.

\subsection{Liability of the hospital to the community}

Liability of hospital to the community are expected to be open, and honest materialize in Abepura Hospital in service to patients, include treatment and curative through the standard operation of the hospital has explained the procedure conducted their Ministry. Through neither brochures nor banners that were posted on the walls of the hospital about the motto, procedure and the other appeal even local newspapers have also been delivering hospital conditions. Similarly, the range of service not only in the area of Abepura but also include some expansion of existing district in Papua.

\subsection{Liability of hospitals toward client/Patient}

Liability of hospital to patient/client, then hospital is required to attend to the patients' rights, provide an explanation of disease and medical action to the patient, asking patients' approval before doing the medical action as well as attend to privacy and secrecy of the patient. Those principles are fundamental have been conducted quite well in the hospital.

\subsection{Liability of the Hospital toward staff/employees}

Liability of hospital toward personnel/staff that have implemented yet in Abepura Regional Public Hospital optimally recruitment, coordination and supervision. In terms of recruitment of human resources, planning is needed and good cooperation both internally and with the Local Government.

\subsection{Liability of hospital in carrying out cooperation with relevant agencies}

In the hospitals' Liability to make good relations with the owner of the local government hospital, Papua Province, with other hospitals or other agencies those carryout tasks in the field of health is running with optimum. However, continuous effort needs to be done to the Government especially in some urgent issues, such as, funding, human resources and medical equipment are needed. 


\section{Conclusion and Suggestion}

\subsection{Conclusions}

1. The application of the principles of the ethics of the Abepura Regional Public Hospital has not yet been implemented optimally, despite being better implementation compared to before the year in 2009. It has not been seen in its optimal implementation of the liability of hospitals, both liability of the hospital, liability of the hospital to the community, liability of hospitals toward client/patient, hospital liability toward staff/employees and liability of the hospital in carrying out cooperation with relevant agencies.

2. There is no the Committee of ethics in Abepura Regional Public Hospital that serves to give consideration to the violation of ethics in hospitals.

\subsection{Suggestions}

1. For Abepura Regional Public Hospital in Jayapura that order the application of hospital ethics runs well and can further improve health services for the community so need to do planning and coordination. Both internally about the needs of hospital medical equipment both medical and non-medical such as hospitality equipment hospitals and medications required as well as the required resources are mainly human resources and infrastructure. Externally conducted intensive coordination with the local Government in the provision is funds and resources needed.

2. Immediately formed the Committee of ethics of the hospital so that it can help management/leadership in resolving conflicts or violations of the ethics in hospitals.

\section{References}

Aditama, Tjandra Yoga. (2007). Management of Hospital Administration. Universitas. Jakarta: Indonesia Press.

Bonczek, Stephen. (1992). Ethical Decision Making. Public Personal Management.

Bertens, K. (2007). Ethical. Seri Filsafat Atmajaya, Jakarta: PT. Gramedia Pustaka

Denhardt, J.V., \& R.B. Denhardt. (1988). The Ethics of Public Service: resolving moral dilemmas in Public Organizations. New York: Greenwood Press.

Gawthrop, L. (1998). Public Service and Democracy, Ethical Imperatives for the 21st Century New York. NYP: Catham House.

Giyai, Aloysius. (2012). Breaking the Death Chain in Papua. Jayapura: Pakar Papua Pustaka Raya.

Hardiyansah. (2011). Public Service Quality Concept, Dimension of Indicator and its implementation. Jogjakarta: Gava Media.

Kumorotomo, Wahyudi. (2002). Ethics of Public Administration. Jakarta: PT Raja Grafindo Persada.

Kumorotomo, Wahyudi. (2008). Accountability of Public Bureaucracy; Sketch in the Period of Transition. Yogyakarta: Pustaka Pelajar.

Lasono, T. (2000). Strategic Aspects of Hospital Management. Yogyakarta: Andi.

Miles, Mathew B., \& Huberma, Michael. (1992). Qualitative Data Analysis. Translated by Tjetjep Rohendi Rohidi. Jakarta: Universitas Indonesia Press.

Notoatmodjo, Soekidjo. (2010). Ethics and Health Law. Jakarta: Rineke Cipta.

Pugh, D. (1991). The Origins of Ethical Frameworks in Public Administration. In James Bowman (Eds.), Ethical Frontiers in Public Management: Seeking New Strategies for Resolving Ethical Dillemmas. San Fransisco: CA Jassey-Bass.

Rasyid, M. Ryaas. (1997). Meaning of Government: Review of the terms of the Ethics and Leadership. Jakarta: PT.Yasif Watampone.

Salusu, J. (2004). Strategic Decision Making for Public Organizations and Non-profit Organizations. Jakarta: PT Gracindo.

Sarundajang, S.H. (2012). Bureaucracy in the Autonomous Region Fighting Failure. Jakarta: Kata.

Sumijatun. (2012). Cultivating Ethics in Nursing Practice. Jakarta: Salemba Medika.

Triwibowo, Cecep. (2012). Licensing and Accreditation of Hospitals. Yogyakarta: Nuha Medika.

Victor, Bart., \& Cullen, J. (1988). The Organizational bases of Ethical Work Climates. Administrative Science Quarterly, 33, (1), 101-125.

Willbern, Y. (1984). Types and Levels of Public Morality. Public Administration Review, 44, (2), 102-108.

Winarno, Budi. (2013). Ethics Development. Yogyakarta: CAPS. 